\title{
Assessing Soil-Related Black Spruce and White Spruce Plantation Productivity
}

\author{
Shane Furze1, Mark Castonguay ${ }^{1}$, Jae Ogilvie ${ }^{1}$, Mina Nasr' ${ }^{1}$, Pierre Cormier ${ }^{1}$, Rolland Gagnon², \\ Greg Adams², Paul A. Arp ${ }^{1}$
}

${ }^{1}$ Forest Watershed Research Center, UNB Faculty of Forestry and Environmental Management, Fredericton, Canada

${ }^{2}$ J.D. Irving Ltd., Sussex, Canada

Email: arp1@unb.ca

How to cite this paper: Furze, S., Castonguay, M., Ogilvie, J., Nasr, M., Cormier, P., Gagnon, R., Adams, G., \& Arp, P. A. (2017). Assessing Soil-Related Black Spruce and White Spruce Plantation Productivity. Open Journal of Forestry, 7, 209-227. https://doi.org/10.4236/ojf.2017.72013

Received: January 14, 2017

Accepted: April 10, 2017

Published: April 13, 2017

Copyright $\odot 2017$ by authors and Scientific Research Publishing Inc. This work is licensed under the Creative Commons Attribution International License (CC BY 4.0).

http://creativecommons.org/licenses/by/4.0/

\begin{abstract}
This article focuses on modelling and mapping the productivity of black (Picea mariana) and white spruce (Picea glauca) plantations across the Black Brook forest management area in northwestern New Brunswick, Canada, encompassing about 200,000 ha. This effort involved establishing $350050 \mathrm{~m}^{2}$ survey plots, each informing about: plantation age (15 to 43 years), planted species type, stem count, tree height, basal area, and wood volume. All of this was supplemented with location-specific productivity predictors, i.e., xy location and specifications pertaining to soil type, soil drainage (established through digital elevation modelling by way of the depth-to-water index DTW), and years since thinning (pre-commercial and commercial), and. The DTW index, as it emulates the elevation rise away from open water features such as streams, rivers and lakes, allowed the re-mapping of existing soil borders by topographic position and drainage association. Non-linear regression analysis revealed that plantation height, basal area and volume all increased with plantation age, as to be expected. Pre-commercial thinning in plantations $<30$ years old had a positive while the more recent commercial thinning still had the negative effect on standing wood volume and mean annual volume increment (MAI). White spruce MAI generally exceeded black spruce (MAI) by a factor of 1.25. Poor and excessive soil drainage reduced MAI. Best growth performances occurred on plantations established on well-drained calcareous soils. The best-fitted results so obtained allowed for generating black and white spruce MAI maps across the forest management area by ridge-to-valley soil and DTW location at $10 \mathrm{~m}$ resolution. These maps were subsequently used for site-by-site silvicultural evaluation and ranking purposes.
\end{abstract}

\section{Keywords}

Forest Plantation Productivity Mapping, Black Spruce, White Spruce, Soil Type \& Drainage, Digital Terrain Modelling 


\section{Introduction}

In general, of forest plantation productivities are not only affected by forest management actions including species selection and stocking level to promote plantation growth and yields but also by climate and soil conditions. This article focuses on aspects pertaining to how differences in soil quality and drainage affect the growth of black and white spruce plantations, with soil type referring to differences in landforms and related surface expressions and geological substrates. Likely soil-related growth and yield affecting differences refer to rooting depth, organic matter and coarse fragment content, and nutrient availabilities as modified by rate of soil weathering, litter decomposition, soil moisture regime and climate. Climate related factors refer to length of growing season, the extent of atmospheric deposition in the form of precipitation (rain, snow, and nutrients such as $\mathrm{N}, \mathrm{S}, \mathrm{Ca}, \mathrm{Mg}$ and $\mathrm{K}$ ), and actual evapotranspiration as dictated by monthly precipitation and air temperature patterns (Keys et al., 2016).

Highest soil productivities can be expected to occur on deep, friable and organically enriched soils with well-functioning root systems. In other soils, root growth is often restricted by high coarse fragment content, soil compaction, lack of aeration, low temperature, and/or the presence of toxic substances (Table 1, Arp \& Krause, 2002). Typically, plantation growth is better maintained by organically enriched soils on well-drained locations due to prolonged retention of plant available water. On poorly to imperfect drainage locations, insufficient soil aeration due to persisting water saturation restricts root development (Kozlowski, 1985; Gale and Grigal, 1987; Drever \& Lertzman, 2001; Crow, 2005; Angstmann et al., 2013). For example, Douglas fir and white spruce do not tolerate low soil aeration, but black spruce, red alder, western cedar, Sitka spruce and western hemlock are adapted to shallow water tables. Rooting is also affected

Table 1. General relationships between soil properties and site quality, including optimal conditions.

\begin{tabular}{|c|c|c|}
\hline Soil property & Relation to site quality & Optimal conditions ${ }^{*}$ \\
\hline Lithology & Affects $\mathrm{K}, \mathrm{Mg}$ and Ca supply & Coarse mafic; calcareous inclusions \\
\hline Soil organic matter content & Source of $\mathrm{N}$ and $\mathrm{P}$, promotes aggregation & Deep accumlations, $>10 \%$ \\
\hline Texture & Affects drainage, water and nutrient storage & Sandy loam, loam, silt loam \\
\hline Structure & Promotes aeration, counteracts compaction and high soil strength & Granular \\
\hline Consistency & Affects soil strength & Friable \\
\hline Drainage & Determines soil moisture regime and aeration status & Moderate to well (fresh) \\
\hline Depth of Ah horizon & Location of high biological activity and nutrient availability & $>10 \mathrm{~cm}$ \\
\hline Stone content & Improves thermal regime, but limits soil volume for rooting & $<15 \%$ \\
\hline Depth to least permeable layer & Limits rooting space, improves moisture regime in coasre soils & $>80 \mathrm{~cm}$ \\
\hline Mottling & Reveals poor soil aeration & $>75 \mathrm{~cm}$ \\
\hline Thickness of B horizon & $\begin{array}{l}\text { Enhances growth through increased clay, organic matter } \\
\text { and nutrient content within rooting space }\end{array}$ & $>30 \mathrm{~cm}$ \\
\hline
\end{tabular}

${ }^{*}$ Classes as defined by the Agriculture Canada Expert Committee on Soil Survey (1987). 


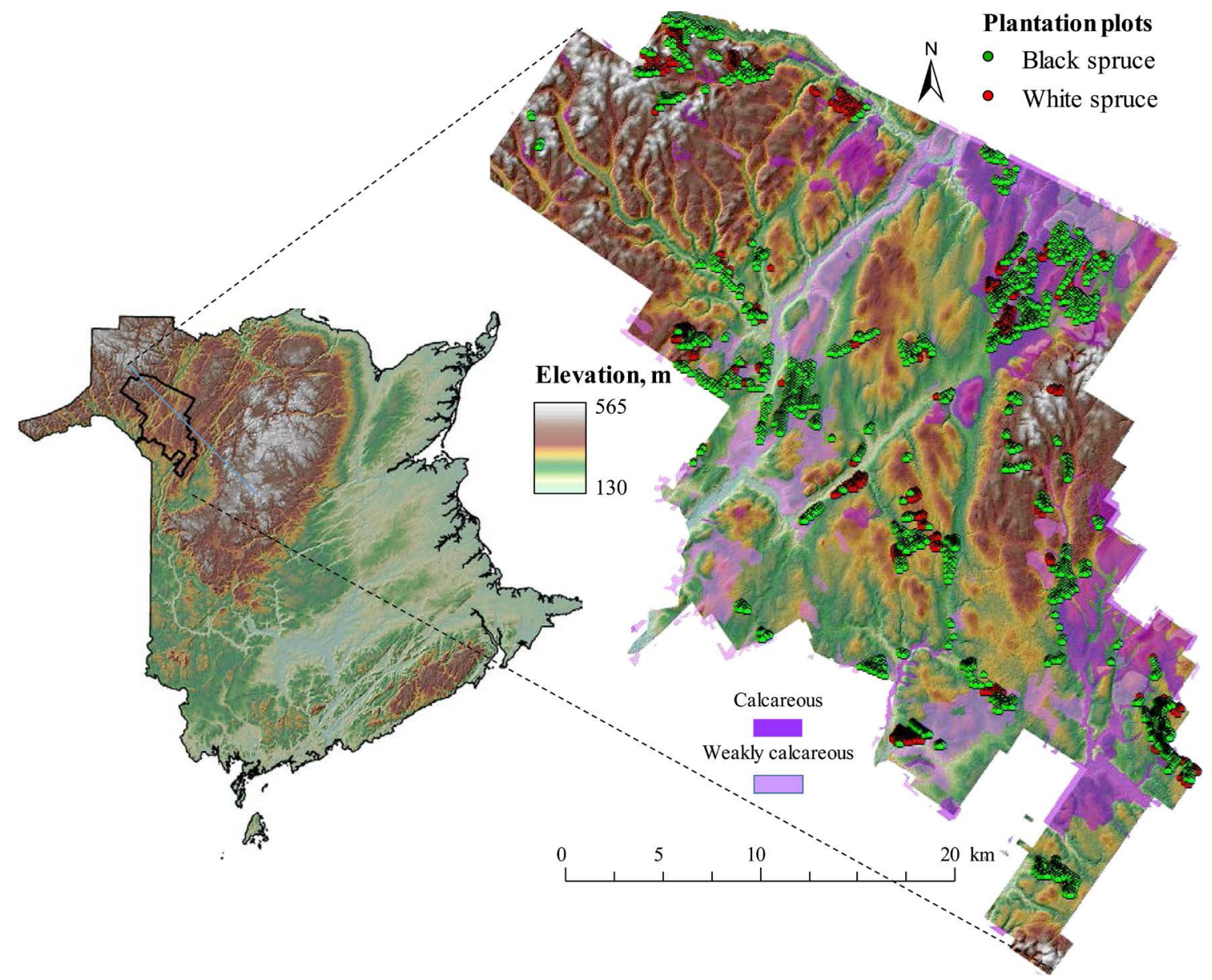

Figure 1. Black Brook forest management area within northwestern New Brunswick, Canada: location, extent, terrain elevation, black and white spruce plantation survey plots, and distribution of soils with calcareous content.

by soil temperatures (Alvarez-Uria and Körner, 2007), being slow and delayed in soils that remain cool as seasons transit from winter to spring and summer. In addition, fine roots are sensitive to acidification, mainly due to acid-induced $\mathrm{Al}$ mobilization (Cronan and Grigal, 1994).

This article focuses on stem count, tree height, basal area and wood volume growth in select black and white spruce plantations across a 250,000 ha forest management area in northwestern New Brunswick (Figure 1). The research involved discerning how these growth metrics are affected by species type (white versus black spruce), soil type and soil drainage. Soil type was defined by type-specific landform and geological substrate combinations, also referred to as soil associations or catenas. Soil drainage type was adjusted to conform to the DTM-derived depth-to-water pattern (DTW) across the land as generated from a $10-\mathrm{m}$ resampled LiDAR-generated digital terrain model (DTM) for the area.

\section{Methods}

\subsection{Study Area}

The forest management area in northwestern New Brunswick refers to the Black 
Brook management zone (longitude -67.66; latitude 47.231) spans elevations from 128 to 569 above sea level (Figure 1). Mean annual precipitation amounts to $1104 \mathrm{~mm}$; mean annual air temperature is $3.5^{\circ} \mathrm{C}$; mean degree growing days above $5^{\circ} \mathrm{C}$ amount to 1532.6 (Environment Canada, 2017). The dominant upland species are Sugar Maple (Acer saccharum) (30\%), Yellow Birch (Betula alleghaniensis) (11\%), and Balsam Fir (Abies balsamea) (10\%). Planted stands cover $33 \%$ of the management zone and consist off White Spruce (Picea glauca, 42\%), Black Spruce (Picea mariana, 40\%), and Norway Spruce (Picea abies, 14\%). Surface deposits vary from alluvium within floodplains, glacio-fluvial along the floodplains, residuals on ridges and steep slopes, and combinations of ablation and/or basal till along generally undulating to rolling terrain (Langmaid et al. 1976; Colpitts et al., 1995; Fahmy et al., 2002). An overview of forest soil units and associated bedrock formations is provided in Table 2.

Table 2. Overview of forest soils and associated bedrock geology, mode of deposition, and lithology of parent material for the Black Brook management zone, northwestern New Brunswick, Canada. Bedrock Geology retrieved from (New Brunswick Department of Natural Resources N.B. DNR, 2008; Fahmy et al., 2010).

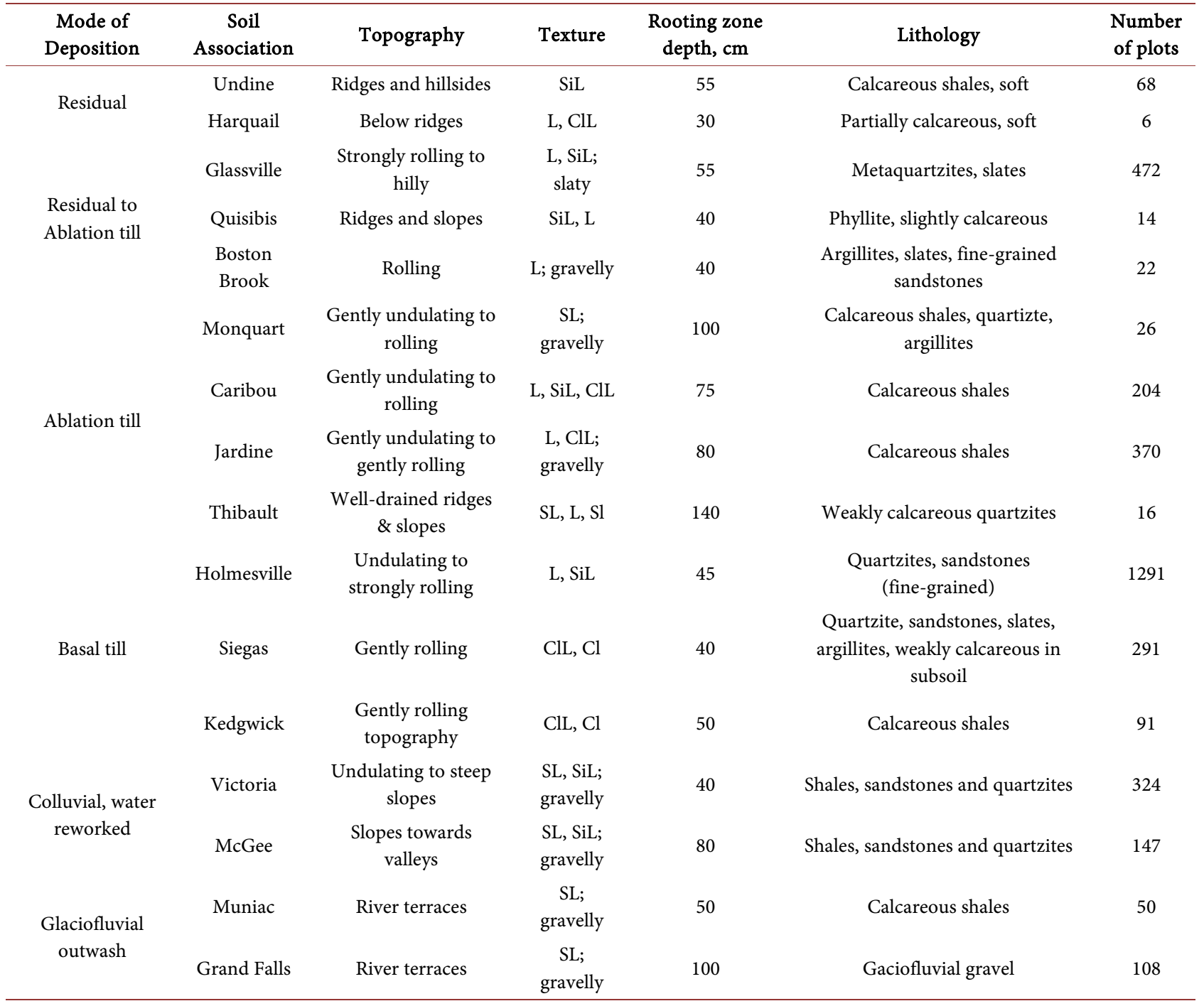

SL: sandy loam, L: loam; SiL: silt loam; ClL: clay loam; Cl: clay. 


\subsection{DTM-Based DTW Delineations}

The DTM raster at 1-m resolution was generated from the 2014 LiDAR pointcloud data for the area, through systematic point-of-last-return classification, followed by natural neighbour interpolation. This DTM was then re-sampled at $10 \mathrm{~m}$ resolution and used to generate the cartographic depth-to-water delineation as developed from the DTM-generated datalayers (Murphy et al., 2011). This delineation involved the following raster-based algorithms: fill, flow direction, flow accumulation, stream network classification (4 ha for stream flow initiation), and determining the cartographic depth-to-water (DTW) pattern as dictated by the least elevation rise away from the stream network pattern for which DTW $=0$. Floodplains were delineated in the same way, by setting the upslope flow-initiation area for floodplain initiation requiring about 400 ha of upstream flow accumulation areas. Each floodplain so located was subsequently delineated by limiting the floodplain elevation rise to DTW $=4 \mathrm{~m}$ away from the DTW $=0$ defining floodplain channels.

\subsection{Soil Association and Mode of Surface Deposition: Shapefile Adjustments}

The DTM-derived slopes and DTW patterns away from the stream and floodplain flow channels were used to hydro-topographically correct the existing soil catena borders to conform to the lake, river, and wetland features of the area. In so doing, open-water features were excluded from the soil polygons, and organic soils would be relocated and/or limited to the extent of the corresponding image-recognized wetland features. Residual soil formations were constrained to occur along steep ridges and slopes only. The lower-lying borders of the till and glacio-fluvial formations were set to coincide with their adjacent DTM-recognized floodplains borders. The existing soil drainage specifications within each soil catena were replaced by the stream-channel based DTW-pattern using the following specifications: $<10 \mathrm{~cm}$, very poor; 10 to $25 \mathrm{~cm}$, poor; 25 to $50 \mathrm{~cm}, \mathrm{im}$ perfect; 50 to $100 \mathrm{~cm}$, moderate; 1 to $20 \mathrm{~m}$ well, $>20 \mathrm{~m}$ excessive. In addition, the geological bedrock formation outlines were adjusted to conform to the lithology descriptions per soil association polygon. The soil types so adjusted are listed in Table 2, by mode of surface deposition, texture, and by lithology with emphasis on calcareous versus siliceous content.

\subsection{Plantation Survey}

In 2007, $350050-\mathrm{m}^{2}$ circular forest development survey plots were used to generate data for stem count, tree height, basal area and stem volume for select black and white spruce plantations across the Black Brook forest management area. These plots were systematically located within select plantation along a 100 $\times 100 \mathrm{~m}$ sampling grid. All planted and non-planted trees were tallied for each plot by species, diameter at breast height. Plot height was set to be the height of tree closest to each grid centre. These determinations were used to estimate stem density (stems/ha), basal area $\left(\mathrm{m}^{2} / \mathrm{ha}\right)$, total volume $\left(\mathrm{m}^{3} / \mathrm{ha}\right)$ and mean annual 
increment $\left(\mathrm{m}^{3} / \mathrm{ha} / \mathrm{year}\right)$ for each plot. Also noted was plantation age and years since pre-commercial $(n=791)$ and commercial $(n=203)$ thinning. Each plot was further characterized by planted species, landform by mode of deposition, soil type, elevation, slope, aspect, and DTW. The number of plots per soil type are listed in Table 2. Due to the nature of the plot survey and the area limitations per soil type, observations per soil type varied widely, from 6 to 1291. In addition, white spruce plantations $(n=1050)$ were generally established on well drained sites.

\subsection{Data Management}

All plot-based numerical and categorical data were compiled into a single spreadsheet, with column headings identifying all the above variables, and each row providing the data entries, one plot at a time. Planted species and soil type per plot were binary coded (present 1 ; not present 0 ). The plot-specific numbers for DTW numbers were transformed into $\log _{10}$ DTW to capture the changing drainage conditions from very wet to dry in a linear fashion. Also added where the DEM-extracted values for slope and elevation for each plot at centre.

\subsection{Regression Model and Analysis}

The compiled data were subject to multivariate nonlinear regression analysis (stepwise backward). Plot-estimated per hectare stem counts, height, basal area, total volume and mean annual total volume increment (MAI = total wood volume / planation age) were used as dependent variables. All the other numerical and binary variables were entered as independent variables. The regression model was formulated as follows:

for stems:

$$
y=a \operatorname{age}^{-b}(1+c \mathrm{WS})[\mathrm{F}(\mathrm{DTW})](1+f \mathrm{CL}+g \mathrm{CT}) \mathrm{SF} ;
$$

for tree height, basal area and total wood volume:

$$
\begin{aligned}
y= & a[1-\exp (-b \text { age })]^{3}(1+c \mathrm{WS})[\mathrm{F}(\mathrm{DTW})] \\
& (\text { Stem_Count } / 2500)^{\mathrm{e}}(1+f \mathrm{CL}+g \mathrm{CT}) \mathrm{SF} ;
\end{aligned}
$$

where WS refers to white spruce (coded 1 when present, zero otherwise for black spruce),

$$
\mathrm{F}(\mathrm{DTW})=x^{d}(1-x)^{1 / d} \text { with } x=\left[\log _{10}(\mathrm{DTW})+h\right] / k \text {, DTW in m, }
$$

$a, b, c e, d, f, g, h, k$ are adjustable coefficients, CL and CT referring to plantations with pre-commercial and commercial thinning operations, and SF as the soil factor, given by

$$
\mathrm{SF}=s_{1}^{\text {soill }} s_{2}^{\text {soil } 2} s_{3}^{\text {soil3 } \cdots,}
$$

with soil types numbered soil1, soil2, soil3 $\cdots$, coded 1 or 0 for presence and absence, respectively, and with $s_{1}, s_{2}, s_{3} \cdots$ as adjustable parameters.

Equations ((1a) and (1b)) differ because stem counts tend to decrease with increasing age due to self-thinning and other processes, while tree height, basal 
area and total stem volume increase asymptotically with age towards upper species-, climate- and soil-moderated limits. The step-wise regression analysis systematically eliminated variables with non-significant predictor coefficients due to low probability $(P<0.001)$ and $t$-values $(t<3)$. The best-fitted regression models served to generate the predictor equations for stem count, tree height, basal area and total tree volume.

\subsection{Plantation Productivity Mapping, by Plantation Type}

The best-fitted model for MAI was used to map MAI across the entire forest management area, using ArcMap procedures guided as follows:

1) Two maps were generated, one for black spruce and one for white spruce.

2) Plantation age was fixed at 20 years.

3) Stem count was fixed at $2500 \mathrm{stems} \cdot \mathrm{ha}^{-1}$, to reflect typical planting stock density.

4) The best-fitted soil coefficients were assigned to each soil type (catena) where present.

5) The effects of pre-commercial and commercial thinning were not considered.

6) The DTW factor was calculated as specified above (Equation (2)).

\subsection{Analytical Limitations}

Even with the availability of the 3500 plot determinations, there is the issue of non-equal representation by plantation type ( $n=1050$ for black spruce; $n=2450$ for white spruce) and soil type (Table 2). In addition, there is an uneven plot distribution across the DTW classes, with the majority located within the $1<$ DTW $<10 \mathrm{~m}$. As result, it was not possible to determine how plantation growth would be affected by species-specific sensitivities to soil type and topographic position outside this DTW range. For that reason, the $h$ and $k$ parameters in Equation (2) were set equal to $h=2.6$, and $k=4.8$ for both species, to enable growth predictions across the entire DTW range from essentially open water conditions to steep ridge tops. In addition, all soil parameters were kept common not only by species but also for stem count, tree height, basal area and total wood volume.

\section{Results}

In total, there were 2450 black spruce and 1050 white spruce plots (Figure 1). The plot-generated variables are presented in Table 3 by listing the basic statistics for plantation age, height, basal area, total volume, MAI, and for the DEM-derived variables $\log _{10}$ DTW, slope, elevation. The histograms of these variables (Figure 2) show wide variations for each these variables, and especially so for the stem-counts: from 20 to 20,400 per hectare. The higher stem count numbers were due to dense non-planted species regenerations. Low stem counts occurred on wet spots, on shallow soils with rock exposures, and densely machine-trafficked areas. A similar stem-count range was reported by Pitt and Lanteigne (2008) in their work on un-thinned and thinned balsam fir and red 
Table 3. Variables informing about site-specific attributes based on plot observations $(n=3500)$.

\begin{tabular}{|c|c|c|c|c|c|}
\hline Plot-generated variables & Units & Mean & Std. Dev. & Minimum & Maximum \\
\hline Age & year $(\mathrm{a})$ & 23.2 & 4.7 & 15 & 43 \\
\hline Since PC-T & year $(\mathrm{a})$ & 2.1 & 4.2 & 0 & 18 \\
\hline Since C-T & year (a) & 0.37 & 1.91 & 0 & 14 \\
\hline Stems & $\mathrm{ha}^{-1}$ & 3805 & 21,805 & 200 & 20,400 \\
\hline Height & $\mathrm{m}$ & 12.3 & 2.9 & 4.7 & 23.34 \\
\hline Basal area & $\mathrm{m}^{2} \mathrm{ha}^{-1}$ & 28.5 & 11.7 & 0.3 & 73.4 \\
\hline Total wood volume & $\mathrm{m}^{3} \mathrm{ha}^{-1}$ & 122 & 69 & 1 & 428 \\
\hline MAI & $\mathrm{m}^{3} \mathrm{ha}^{-1} \mathrm{a}^{-1}$ & 5.1 & 2.4 & 0 & 15.2 \\
\hline Elevation & $\mathrm{m}$ & 273 & 49 & 184 & 5010 \\
\hline Slope & $\%$ & 8.7 & 6.8 & 0 & 53.4 \\
\hline $\log _{10}$ DTW & $\log _{10} \mathrm{~m}$ & 0.58 & 0.46 & -1.87 & 1.9 \\
\hline
\end{tabular}
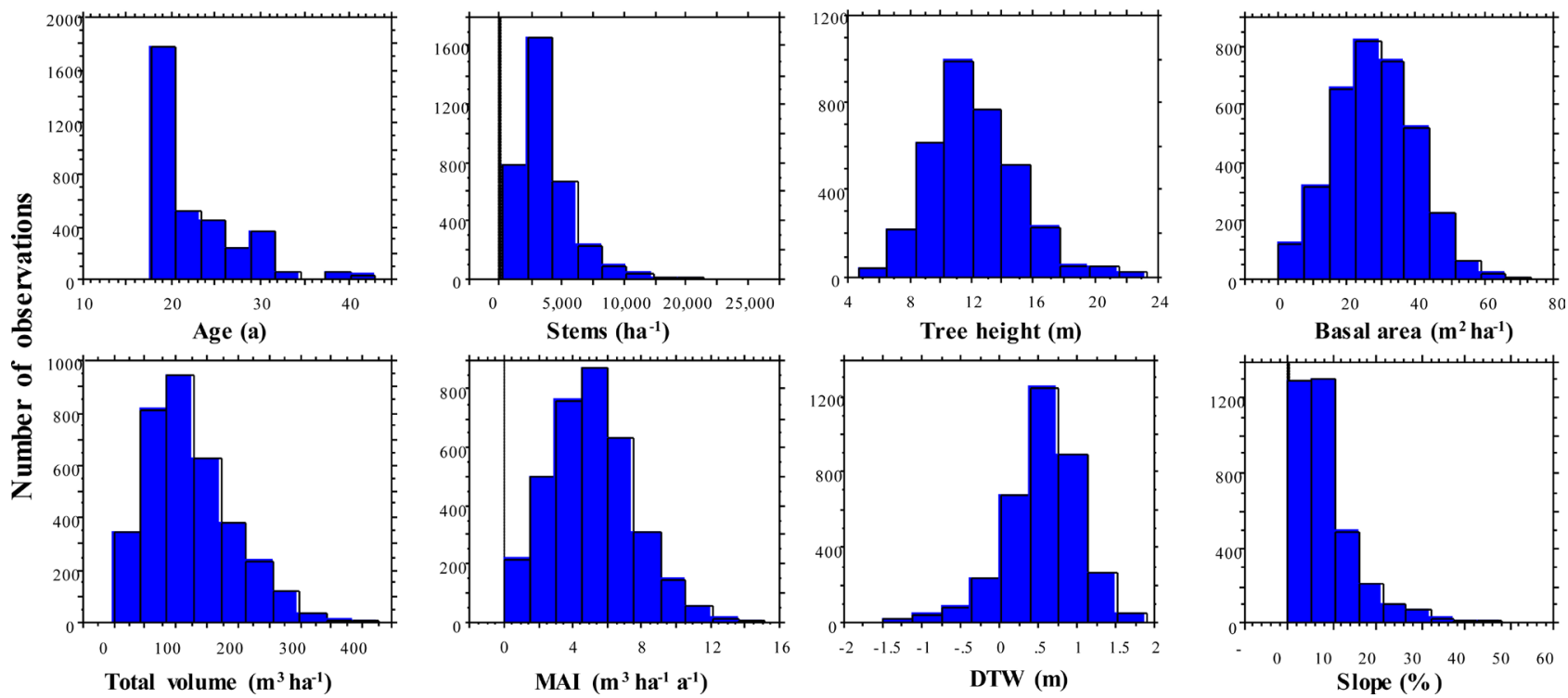

Figure 2. Histograms for the plot-generated plantation variable attributes $(n=3500)$.

spruce thinning trials in northwestern New Brunswick. These trials were conducted 13 to 16 years within harvest blocks that were clear-cut between 1946 and 1955, with post-thinning stem counts, basal areas, total volumes and other forest metrics recorded at 5-year intervals up to 43 years after thinning. In comparison with these trials, the above plot-estimated values for basal areas and total volumes from plantation age 15 to 43 correspond to the Green River results 5 to 33 years after thinning. Hence, the plantations already reached similar basal area and total volume growth at 15 years after establishment than what was noted for the naturally re-generating un-thinned and thinned Green River blocks 20 years after harvesting.

\subsection{Best-Fitted Regression Coefficients}

The best-fitted regression coefficients for stem count tree height, basal area and total volume by way of Equation (1) are listed in Table 4 and Table 5. Also shown are their least-squares coefficient estimates, and associated errors of esti- 
Table 4. Best-fitted regression coefficients for stem count tree height, total wood volume, and basal area by plantation age, white versus black spruce, soil moisture regime (quantified by way of DTW), and thinning intervention (all $p$ values $<0.001$ except larger where absolute $t$-values $<4)$.

\begin{tabular}{|c|c|c|c|c|c|c|c|c|c|c|c|c|c|}
\hline & \multirow{3}{*}{ Parameters } & \multicolumn{3}{|c|}{ Stem Count } & \multicolumn{3}{|c|}{ Tree Height } & \multicolumn{3}{|c|}{ Basal Area } & \multicolumn{3}{|c|}{ Total Wood Volume } \\
\hline & & \multicolumn{3}{|c|}{$\mathrm{ha}^{-1}$} & \multicolumn{3}{|c|}{$\mathrm{m}$} & \multicolumn{3}{|c|}{$\mathrm{m}^{2} \mathrm{ha}^{-1}$} & \multicolumn{3}{|c|}{$\mathrm{m}^{3} \mathrm{ha}^{-1}$} \\
\hline & & Coeff. & $\begin{array}{l}\text { St. } \\
\text { Error }\end{array}$ & t-value & Coeff. & $\begin{array}{l}\text { St. } \\
\text { Error }\end{array}$ & t-value & Coeff. & $\begin{array}{l}\text { St. } \\
\text { Error }\end{array}$ & t-value & Coeff. & $\begin{array}{l}\text { St. } \\
\text { Error }\end{array}$ & $\mathrm{t}$-value \\
\hline & a & 3.00 & 0.40 & 7.5 & 85.5 & 1.4 & 61.5 & 472 & 42 & 11.3 & 3782 & 597 & 6.3 \\
\hline $\mathrm{b}$ & Age adjustor & 0.46 & 0.04 & 10.7 & 0.090 & 0.001 & 64.0 & 0.044 & 0.002 & 20.2 & 0.029 & 0.002 & 13.7 \\
\hline c & $\begin{array}{l}\text { White spruce } \\
\text { adjustor }\end{array}$ & -0.24 & 0.01 & -17.0 & 0.035 & 0.006 & 5.8 & 0.107 & 0.016 & 6.8 & 0.25 & 0.03 & 9.6 \\
\hline $\mathrm{d}$ & $\mathrm{f}(\mathrm{DTW})$ exponent & 1.24 & 0.02 & 55.1 & 1.43 & 0.01 & 106.7 & 1.60 & 0.04 & 39.6 & 1.57 & 0.03 & 53.0 \\
\hline e & $\begin{array}{l}\text { Stem count } \\
\text { exponent }\end{array}$ & \multicolumn{3}{|c|}{ not applicable } & -0.42 & 0.015 & -27.7 & -0.15 & 0.04 & -3.9 & 0.09 & 0.05 & 1.8 \\
\hline$f$ & $\begin{array}{l}\text { Pre-commercial } \\
\text { thinning adjustor }\end{array}$ & -0.068 & 0.019 & -3.5 & -0.042 & 0.006 & -6.6 & 0.017 & 0.020 & 0.9 & 0.074 & 0.025 & 3.0 \\
\hline $\mathrm{g}$ & $\begin{array}{c}\text { Commercial } \\
\text { thinning adjustor }\end{array}$ & -0.58 & 0.03 & -19.2 & -0.25 & -0.02 & 16.5 & -0.50 & 0.03 & -16.4 & -0.25 & 0.05 & -5.0 \\
\hline & $\mathbf{R}^{2}$ & \multicolumn{3}{|c|}{0.239} & \multicolumn{3}{|c|}{0.583} & \multicolumn{3}{|c|}{0.414} & \multicolumn{3}{|c|}{0.535} \\
\hline
\end{tabular}

Table 5. Best-fitted regression coefficients for stem count tree height, total wood volume, and basal area by soil type (all $p$-values $<$ 0.001).

\begin{tabular}{|c|c|c|c|c|c|c|c|c|c|c|c|c|}
\hline \multirow{3}{*}{ Soil type } & \multicolumn{3}{|c|}{ Stem Count } & \multicolumn{3}{|c|}{ Tree Height } & \multicolumn{3}{|c|}{ Basal Area } & \multicolumn{3}{|c|}{ Total Wood Volume } \\
\hline & \multicolumn{3}{|c|}{$\mathrm{ha}^{-1}$} & \multicolumn{3}{|c|}{$\mathrm{m}$} & \multicolumn{3}{|c|}{$\mathrm{m}^{2} \mathrm{ha}^{-1}$} & \multicolumn{3}{|c|}{$\mathrm{m}^{3} \mathrm{ha}^{-1}$} \\
\hline & Coeff. & $\begin{array}{l}\text { St. } \\
\text { Error }\end{array}$ & t-value & Coeff. & $\begin{array}{l}\text { St. } \\
\text { Error }\end{array}$ & t-value & Coeff. & $\begin{array}{c}\text { St. } \\
\text { Error }\end{array}$ & t-value & Coeff. & $\begin{array}{l}\text { St. } \\
\text { Error }\end{array}$ & $\mathrm{t}$-value \\
\hline Muniac & 0.51 & 0.06 & 8.5 & 0.79 & 0.03 & 26.6 & 0.87 & 0.08 & 10.8 & 0.28 & 0.05 & 5.2 \\
\hline Siegas & 0.53 & 0.04 & 14.9 & 0.92 & 0.02 & 36.9 & 0.75 & 0.06 & 13.1 & 0.41 & 0.03 & 12.3 \\
\hline Victoria & 0.61 & 0.04 & 15.0 & 0.92 & 0.03 & 36.4 & 0.75 & 0.06 & 13.2 & 0.50 & 0.04 & 12.2 \\
\hline Monquart & 0.65 & 0.08 & 8.3 & 0.93 & 0.04 & 24.0 & 0.83 & 0.10 & 8.7 & 0.51 & 0.08 & 6.7 \\
\hline Glassville & 0.72 & 0.04 & 16.3 & 0.99 & 0.03 & 37.8 & 0.77 & 0.06 & 13.4 & 0.58 & 0.04 & 13.1 \\
\hline McGee & 0.67 & 0.05 & 14.6 & 0.99 & 0.03 & 35.5 & 0.84 & 0.07 & 12.6 & 0.60 & 0.05 & 12.7 \\
\hline $\begin{array}{c}\text { Boston } \\
\text { Brook }\end{array}$ & 0.84 & 0.08 & 10.9 & 0.95 & 0.04 & 24.8 & 0.62 & 0.09 & 7.1 & 0.66 & 0.07 & 8.9 \\
\hline Holmesville & 0.74 & 0.04 & 16.8 & 1.00 & 0.03 & 38.4 & 0.84 & 0.06 & 14.0 & 0.67 & 0.05 & 14.3 \\
\hline Grand Falls & 0.73 & 0.05 & 13.9 & 0.96 & 0.03 & 34.3 & 0.86 & 0.07 & 12.2 & 0.67 & 0.06 & 11.9 \\
\hline Quisibis & 0.85 & 0.11 & 7.5 & 0.94 & 0.05 & 18.9 & 0.93 & 0.12 & 7.8 & 0.72 & 0.13 & 5.5 \\
\hline Harquail & 0.87 & 0.16 & 5.3 & 0.91 & 0.07 & 13.1 & 0.99 & 0.16 & 6.3 & 0.77 & 0.20 & 3.8 \\
\hline Thibault & 0.88 & 0.10 & 8.6 & 0.97 & 0.05 & 20.0 & 1.09 & 0.12 & 9.3 & 0.80 & 0.12 & 6.7 \\
\hline Jardine & 0.83 & 0.05 & 16.4 & 1.10 & 0.03 & 37.5 & 1.02 & 0.07 & 13.6 & 0.87 & 0.06 & 14.5 \\
\hline Caribou & 1.04 & 0.06 & 16.7 & 1.10 & 0.03 & 37.7 & 1.11 & 0.08 & 13.8 & 1.09 & 0.08 & 14.3 \\
\hline
\end{tabular}


mation and t-values.

Stem counts within the black and white spruce decreased with age, as quantified by the age exponent, i.e., $b=-0.45$. In comparison, white spruce generally had lower stem counts than black spruce, i.e., the stem count adjustment for white spruce was negative, i.e. $c=-0.240$. This would be due to the difference in canopy extent, being wider and therefore more vegetation suppressant and less light transmitting than black spruce (Canham et al., 1994, Power et al., 2012). Not surprisingly, thinning had a negative effect on stem count, but this effect was quite small as per the pre-commercial thinning adjustment factor given by $(1-f C L)=0.932$. In contrast, the commercial thinning operations reduced the stem counts by a factor of $(1-g \mathrm{CT})=0.421$, respectively. This difference may be due to continuing in-growth of natural regenerating species, and this ingrowth would have occurred over a longer time period since the precommercial than the commercial thinning operations.

Tree height also increased with plantation age in a non-linear fashion, i.e., starting slow at first before accelerating for about forty years. Thereafter, height growth is expected to slow down, as formulated by the $[1-\exp (-b \text { Age })]^{3}$ expression in Equation (1b), for which the best-fitted age adjustor for tree height equals 0.090 year $^{-1}$ (Table 4). High stem counts had a depressing effect on tree height as indicated by the negative stem-count exponent for tree height, i.e., (Stem_ count/2500) $)^{-0.42}$. This would likely be due to conspecific neighbourhood competition as reported by Smith et al. (2015). In addition, height was slightly taller for white than for black spruce: white spruce height $=1.035$ black spruce height. Hence, for same soil conditions, a $20 \mathrm{~m}$ tall black spruce tree would be equivalent to a $20.7 \mathrm{~m}$ tall white spruce, all other conditions (age, time since thinning, stem counts) being the same. Generally, tree height was slightly depressed by the thinning operations, with the commercial thinning operations having a somewhat larger effect than the pre-commercial thinning operations. This could be due to a removal of some of the taller non-planted species. Generally, thinning operations have no effect on tree height, but there are positive and negative exceptions as well (Lanner, 1985; Masaka et al., 2013; McKinnon et al., 2006).

Both basal area and total wood volume accelerated with age within the plantation age range up to 40 years, with white spruce outperforming black spruce in total basal area and wood volume accumulations by a factor of 1.07 and 1.25 , respectively (Table 4 ). The latter number is higher than what was found by Mallik et al. (2008) by way of white versus black spruce experimentation, but similar to what was reported by Homagain et al. (2011) for same aged black and white spruce plantations in northwestern Ontario. Hence, the wood volume productivity is $25 \%$ higher for white spruce than for black spruce plantations, all other conditions (age, soil type, time since thinning) being the same. These differences, however, may increase or decrease as the plantations age further (Homagain et al., 2011). In terms of the post-thinning effects, there were small but significant basal area and wood volume benefits stemming from the pre-commercial but not yet from the more recent commercial thinning opera- 
tions. This would be due to the intended basal area and wood volume reductions at the time of commercial thinning, and could in part also be due to post-commercial thinning mortality (Thorpe et al., 2008).

With respect to soil drainage, stem count, tree height, basal area and total wood volume were all similarly affected, being optimal within the $1<$ DTW $<10$ $\mathrm{m}$ range, with tree height, basal area and wood volume productivity somewhat more sensitive to extreme soil moisture regimes than stem count. This is in agreement with Wang and Klinka (1996) who provided the following metric tree height index assessment of Ontario in terms of the soil moisture regime variations: moderately dry, $15.8 \mathrm{~m}$; slightly dry, $20 \mathrm{~m}$; fresh, $20.5 \mathrm{~m}$; moist, $20 \mathrm{~m}$; very moist $16.3 \mathrm{~m}$; wet, $13 \mathrm{~m}$; very wet, $5.8 \mathrm{~m}$.

With respect to soil type, there were also significant differences for stem count, tree height, basal area and total wood volume, as listed in Table 5. In particular, this list revealed that the effects of soil type on wood volume productivity were most strongly correlated to the soil type contributions pertaining to basal area and tree height, but were only weakly correlated to the soil contributions pertaining to stem count (Table 6). Sorting the soil contributions to wood volume (or MAI) from low to high indicated that the greatest gains in wood volume occurred on well-drained and medium texture calcareous soils (Figure 3). The lowest gains occurred on coarse-textured and gravelly outwash plain soils $(\mathrm{Mu}-$ niac) and fine-textured basal till soils (Siegas). Among the soils on siliceous substrate, plantation productivity decreased with increasing stoniness: least for Holmesville, and most pronounced for Victoria. The ranking of the best-fitted regression coefficients between total wood volume and soil type generally agrees with the soil property descriptions in Table 2, whereby the Caribou, Undine and Kedgwick soils encompass most if not all of the optimal soil conditions as per Table 1. The opposite applies to the Muniac and Siegas soils.

The multivariate regression results varied in the amount of plot-to-plot variance explained, i.e., $\mathrm{R}^{2}=0.228$ for stem counts, 0.588 for tree height, 0.399 for basal area, and 0.530 for tree volume (Table 4). Hence, much of the plot-to-plot variations remain unresolved by way of Equations (1)-(3), and especially so for stem count. Choosing MAI as dependent variable explained 33\% of the overall MAI variations. The spread of the regression-generated best-fitted residuals for tree height, basal area, total wood volume and MAI are plotted in Figure 4 and

Table 6. Best-fitted multiple regression results for the best-fitted soil type contributions to total wood volume (Table 5), using the best-fitted soil type contributions for basal area, tree height and stem count (Table 5) as predictor variables.

\begin{tabular}{ccccc}
\hline Variable & Coeff. & Std. Error & t-Value & P-Value \\
\hline Intercept & -1.00 & 0.09 & -10.6 & $<0.0001$ \\
Basal Area & 0.89 & 0.07 & 12.5 & $<0.0001$ \\
Tree height & 0.81 & 0.12 & 6.8 & $<0.0001$ \\
Stem Count & 0.23 & 0.06 & 3.9 & 0.0024 \\
\hline
\end{tabular}




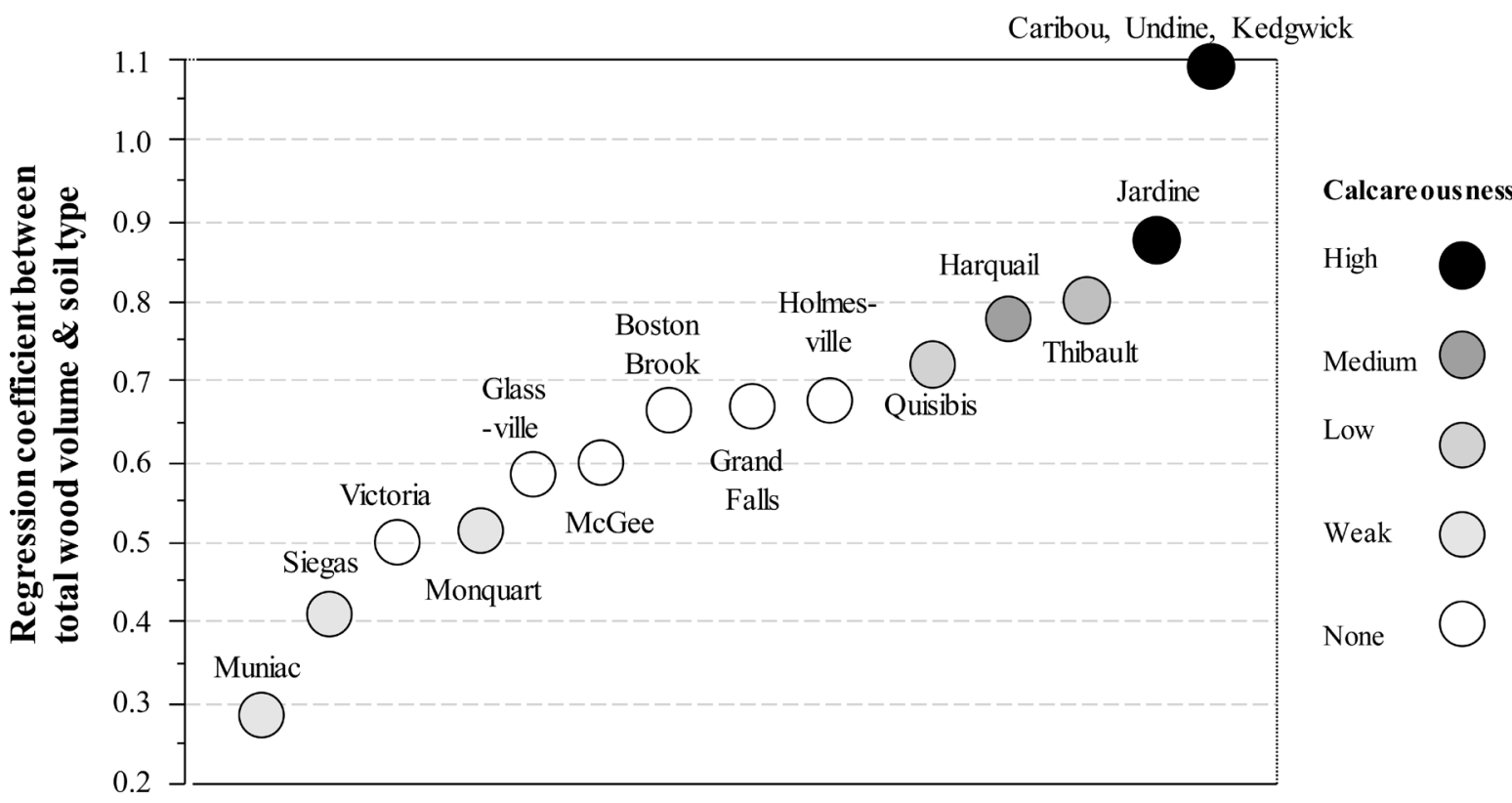

Figure 3. Arranging the regression coefficients between total wood volume and soil type (Table 5) from low to high.

Figure 5 by way of scatterplots and histograms. These results are similar to what is normally found across plot-based modelling efforts, as documented by, e.g., Pinjuv et al. (2007) in Dykstra (2007). Using actual instead of modelled stem counts improved the analytical results slightly by increasing regression-captured variations towards $R^{2}$ values amounting to 0.613 for basal area, 0.676 for total wood volume, and 0.434 for MAI. This small increase is not surprising since the plot-based basal area and volume estimates already include the plot-generated stem-count estimates. By plot-to-model comparisons, the following $80 \%$ conformance results were obtained: \pm 1300 stems $\mathrm{ha}^{-1}, \pm 3.8 \mathrm{~m}$ for tree height, \pm 11 $\mathrm{m} \cdot \mathrm{ha}^{-1}$ for basal area, $\pm 55 \mathrm{~m}^{3} \cdot \mathrm{ha}^{-1}$ for total wood volume, and $2.2 \mathrm{~m}^{3} \cdot \mathrm{ha}^{-1} \cdot \mathrm{year}^{-1}$ for MAI (Figure 6).

\subsection{Limitations}

The above results do not match the precision that is generally needed for forest related growth and yield predictions. This is in part due to:

i) Procedural issues, whereby the plots were selected for a one-time grid evaluation of the overall plantation growth response variations. For best growth and yield results, plots need to be re-measured at pre-determined intervals.

ii) The age-limited distribution of the plantations. This limitation does not allow for calibrating Equations (1)-(3) beyond 40 years. The exponent of the age-dependent part, i.e. $[(1-\exp (1-b \text { age }))]^{3}$, was therefore set at 3 to allow for the curvilinear fit for height, basal area and total wood volume within the 0 to 40 -year range. The extent to which this determination remains valid beyond age 40 requires further research.

iii) The unequal distribution of the plots by age, species and soil type and drainage conditions. This limits the extent to which the above results fully represent the entire variations across these conditions. For example, the results obtained 

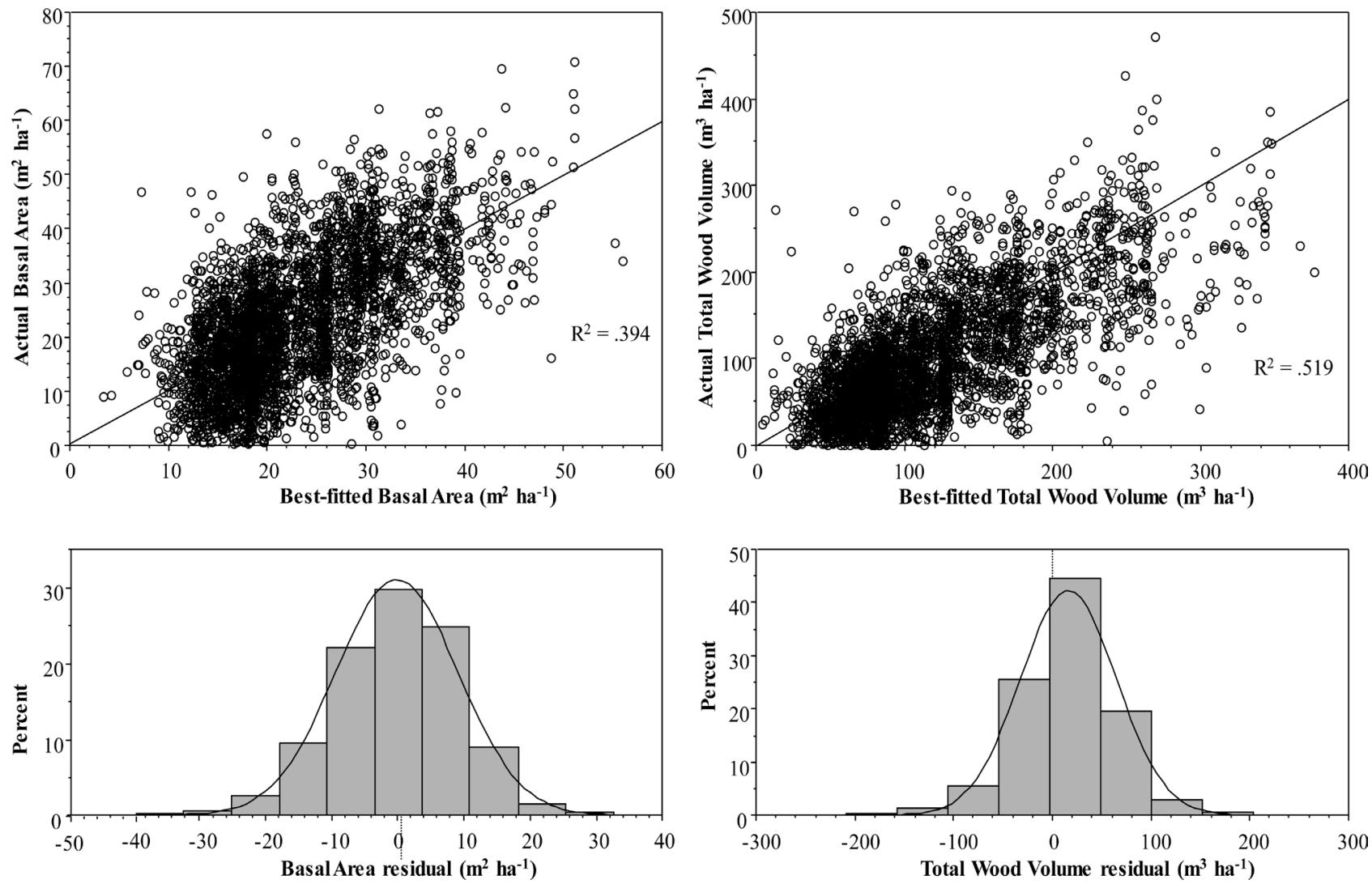

Figure 4. Best-fitted scatterplots and histograms for the best-fitted residuals for basal area and total wood volume $(n=3500)$.
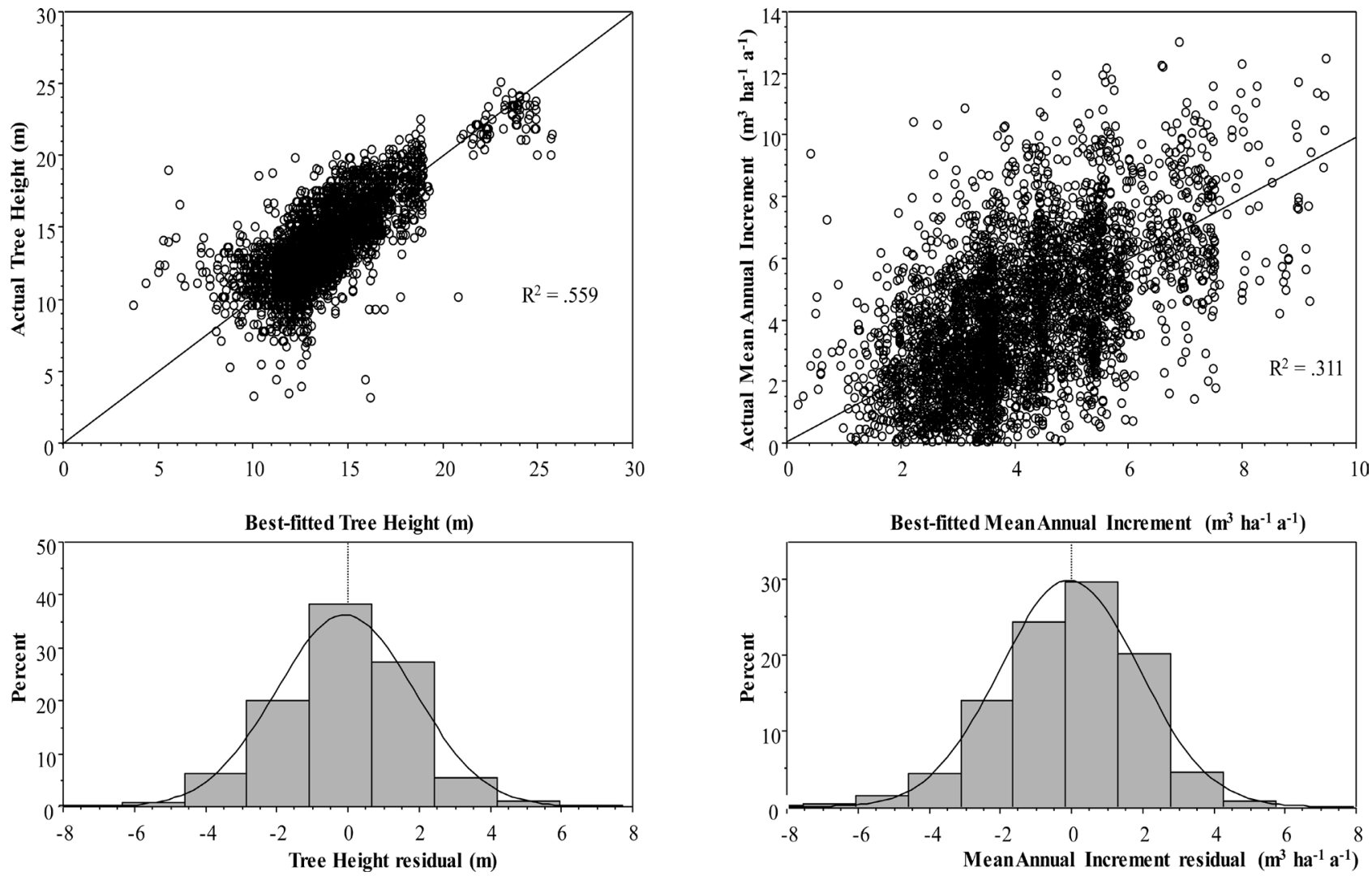

Figure 5. Best-fitted scatterplots and histograms of the best-fitted residuals for plantation height, and MAI $(n=3500)$. 


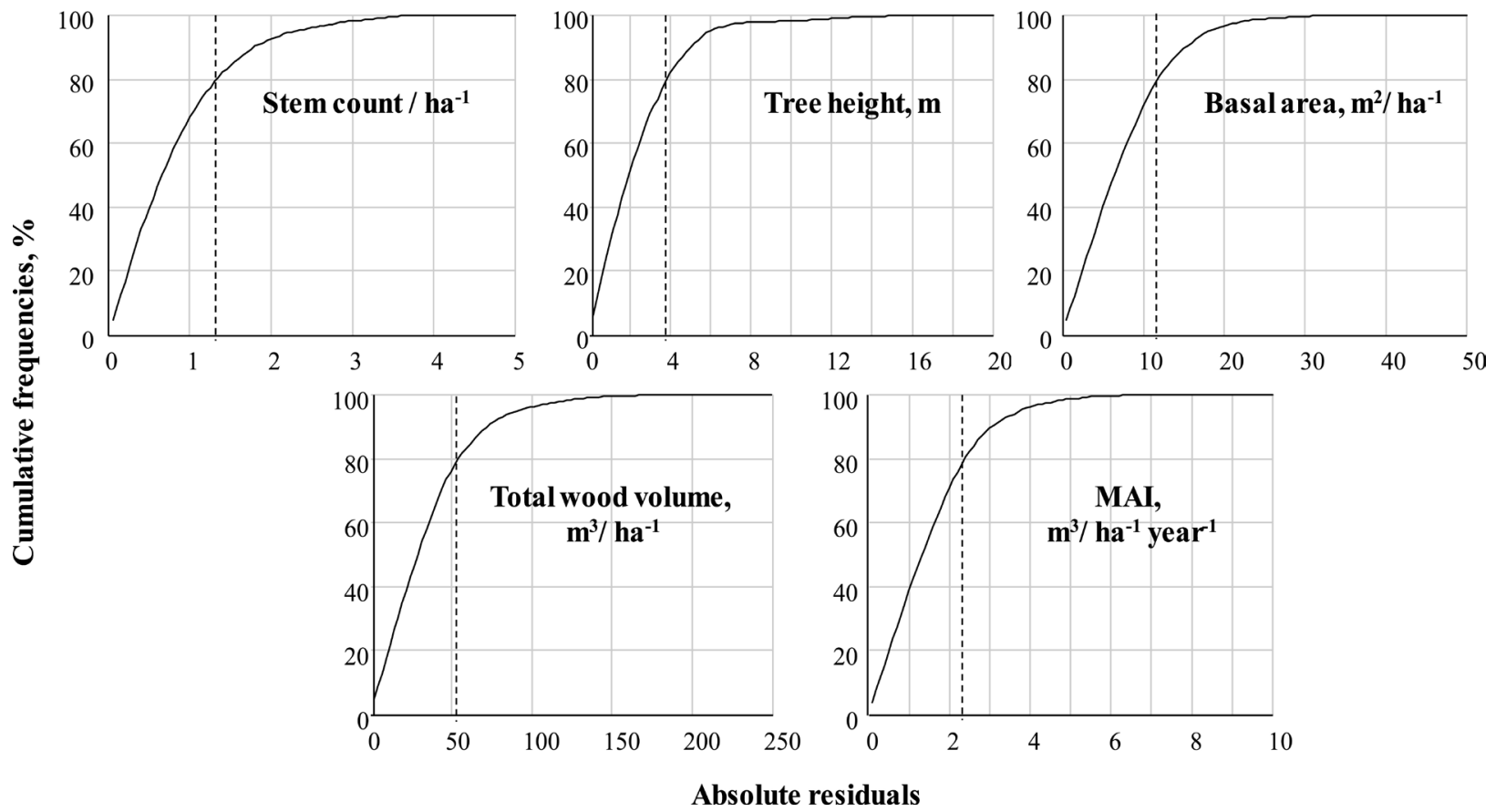

Figure 6. Conformance plots showing the cumulative frequencies of the absolute residual between the individual plot determinations and corresponding best-fitted model results for stem count, tree height, basal area, total wood volume, and mean annual increment (MAI).

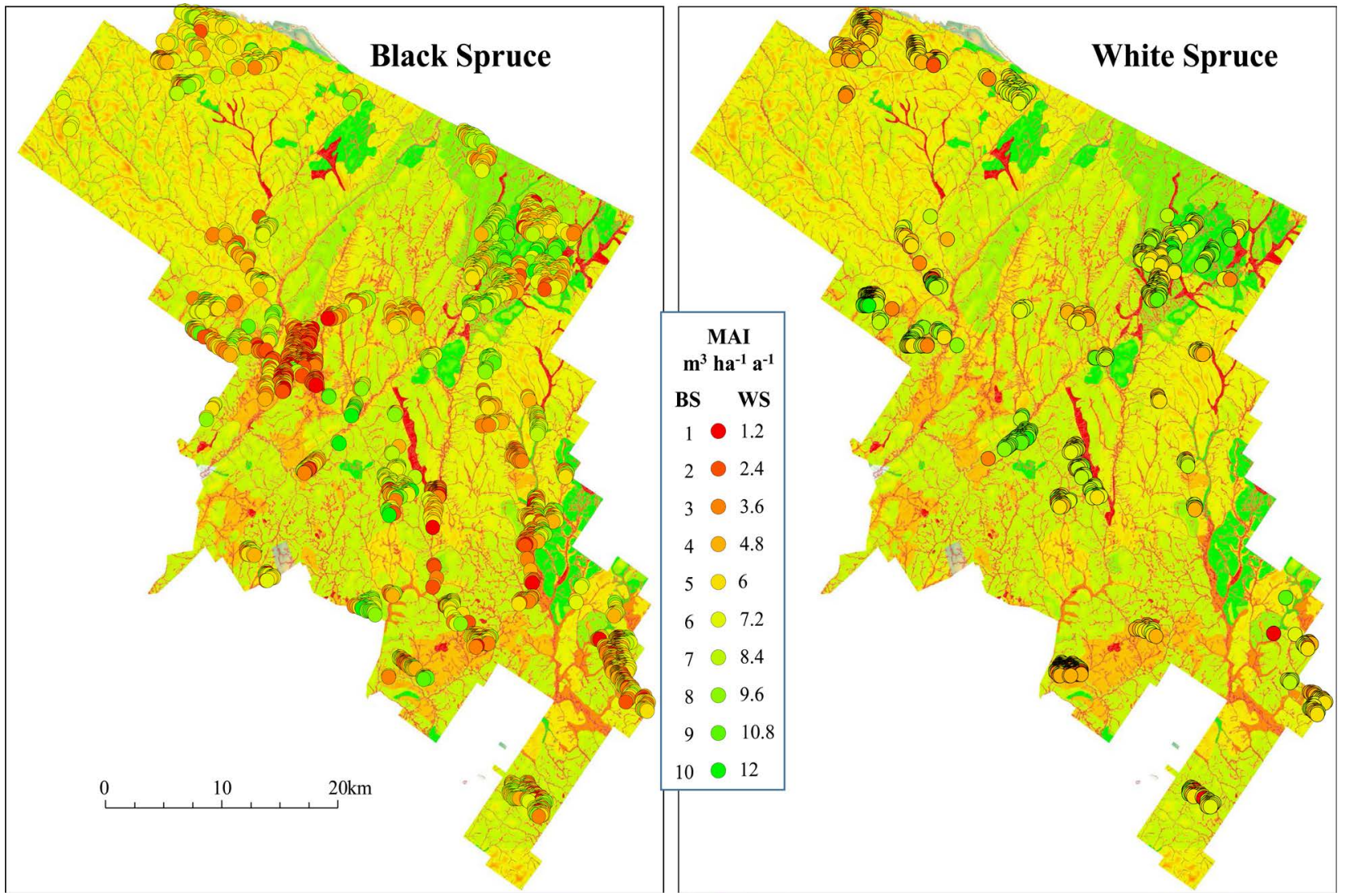

Figure 7. Mean Annual Productivity (MAI) projections [Equations (1b)-(3)] for 20-year old black (left) and white (right) spruce plantations within the Black Brook Forest Management area, with plot-generated MAI estimates (dots) overlaid. 
for the less frequent soil types would be more influenced by chance occurrences and outliers than the results obtained for the more frequent soil types.

iv) The need to map growth-affecting soil properties, from ridge tops to valleys mapping, with soil properties referring to soil rooting depth, texture, organic matter, coarse fragment content and mineralogy. Doing this requires further in-depth studies and model calibrations.

v) For generalization purposes, the evaluations need to be placed into the context of regionally varying climate and atmospheric deposition conditions (Keys et al., 2016).

In addition to the above plot-based evaluations, one could use LiDAR-generated forest metrics for stem counts, tree height, basal and total wood volume at the tree-by-tree level, with, e.g., $20 \times 20$ or $25 \times 25 \mathrm{~m}^{2}$ summations (Strunk et al. 2008; Woods et al., 2011; Treitz et al., 2012; Wulder et al., 2012; Latifi et al., 2015). In doing this, Tompalski et al., 2016 reported the following relative root mean square differences between air-borne laser scanned and stand-matched yield curve projections regarding select forest stands on Vancouver Island: for maximum tree height, $31.1 \%$; for basal area, $19.8 \%$; for total stem volume, 21.8\%; all at a stand-level age of 80 years. This was done through single-tree summations for $9559.25 \times 25 \mathrm{~m}^{2}$ grid plots representing four western species groups (hemlock, cedar, fir/spruce, alder). Overall tree height and stem wood volumes amounted to $33 \mathrm{~m}$, and $576 \mathrm{~m}^{3} \cdot \mathrm{ha}^{-1}$.

Since productivity may range from low to high on imperfectly to poorly drained soil based on micro-topographic mound to pit variations, it would be important to examine this aspect as well. However, whether this detail can be generated from LiDAR-DTMs remains to be seen, because point densities for LiDAR-generated ground reflections can be quite low underneath densely spaced forest plantations. It may, however be possible to infer the extent of mound-and pit surface expressions based on soil type characteristics that lead to wind-induced tree uprooting due to shallow rooting.

\subsection{MAI Productivity Mapping}

The best-fitted Equations (1)-(3) were used to produce white and black spruce MAI productivity maps at age 20 across the entire Black Brook forest management area, as shown in Figure 7, with excerpts in Figure 8(a) and Figure 8(b). Overlaid on these maps are the plot-based black and white spruce plantation MAI determinations. In general, these maps illustrate that the overall landscape dependence of MAI is-apart from plantation age and species-mainly affected by soil type and drainage. In detail, MAI is lowest in wet spots, is best along the lower portions of rolling to hummocky slopes, and gradually decreases from there towards steeper ridge tops. The positive effect of soil type on MAI is most pronounced on deep and well-drained soils with calcareous content, such as the Caribou, Jardine, Kedgwick and Undine soils.

\section{Concluding Remarks}

Examining the results of the 3500 forest development survey plots in relation to 

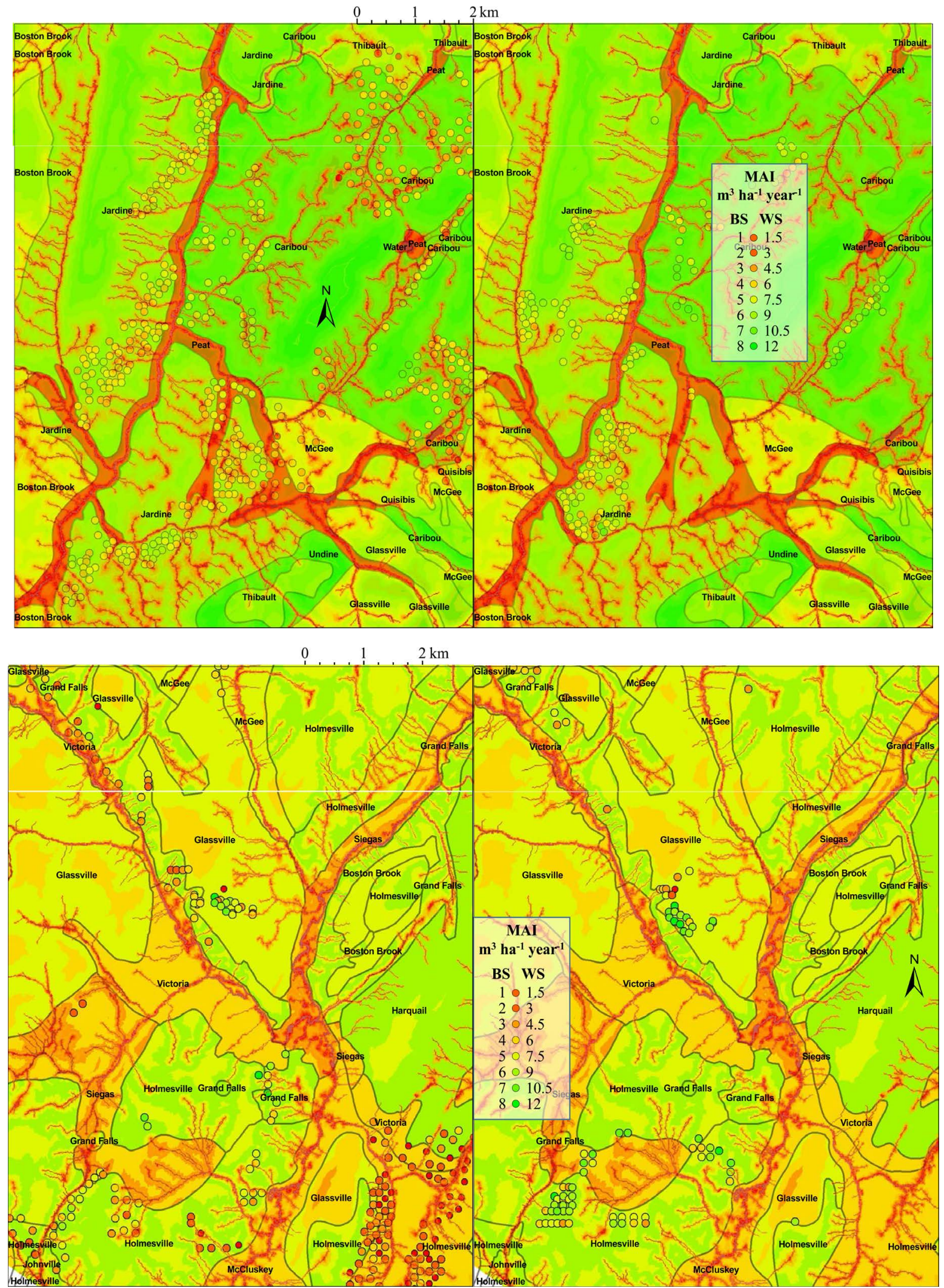

Figure 8. Actual versus mapped MAI conformance details from Figure 7 for the black and and white spruce plantations (left and right sides of panels, respectively) within the Black Brook Forest Management area. Top: part of the top eastern management area, centered on mostly calcareous soils (Caribou, Jardine). Bottom: part of the mid-western management area, centered on siliceous soils (Glassville, Holmesville, Victoria, Grand Falls). 
plantation age, planting stock, thinning operations, soil type and drainage allowed for the development of a generalizable model (Equations (1)-(3)). The resulting best-fitted model was used to estimate and predict the productivities of black and white spruce plantations by soil type, from ridge tops to valleys based on theoretical considerations: e.g., no growth on wet soils and fully exposed bedrock, and varying growth expectations by soil type as affected by substrate lithology, texture and accessible rooting depth. In view of currently forthcoming forest metrics that detail tree-by-tree performances in terms of stem count, height, basal area and wood volume within, e.g., each $20 \times 20 \mathrm{~m}^{2}$ square across entire forest management areas, more of this could be done at a much finer resolution. Doing so is promising because-even in view of the above limitations-about one third to one half of the plot-based productivity variations for tree height, basal area and total wood volume can be quantified using Equations (1)-(3). While the results so generated are still insufficient for precise growth and yield predictions across the plantations and beyond the existing age range, they are providing a starting point for further soil factor quantifications in forest management. At this stage, the mapped white and black spruce projections in Figure 6 and Figure 7 provide a semi-quantitative bases for stand- and sitespecific ranking purposes, and-as such-are being used for directing silvicultural operations (harvesting, site preparations, seedling stock selection planting, thinning) away from low productivity sites that are either too wet or too dry.

\section{Acknowledgements}

This work was supported by NSERC by way of a Discovery grant, contributions from the NSERC-supported AWARE project, and from the Canadian Fibre Centre (Dynamic Forest Inventory Project). Special thanks go to J.D. Irving, Ltd. for data access (forest inventory, plot data, and LiDAR DEM).

\section{References}

Alvarez-Uria, P., \& Körner, C. (2007). Low Temperature Limits of Root Growth in Deciduous and Evergreen Temperate Tree Species. Functional Ecology, 21, 211-218. https://doi.org/10.1111/j.1365-2435.2007.01231.x

Angstmann, J. L., Ewers, B. E., Barber, J., \& Kwon, H. (2013). Testing Transpiration Controls by Quantifying Spatial Variability along a Boreal Black Spruce Forest Drainage Gradient. Ecohydrology, 6, 783-793.

Canham, C. D., Finzi, A. C., Pacala, S. W., \& Burbank, D. H. (1994). Causes and Consequences of Resource Heterogeneity in Forests: Interspecific Variation in Light Transmission by Canopy Trees. Canadian Journal of Forest Research, 24, 337-349.

https://doi.org/10.1139/x94-046

Colpitts, M. C., Fahmy, S. H., MacDougall, J. E., Ng, T. T., McInnis, B. G., \& Zelazny, V. F. (1995). "Forest Soils of New Brunswick" and Maps, CLBRR Contribution (pp. 95-38). Fredericton: New Brunswick Dept. of Nat. Resources and Energy, Agriculture and Agri-Food Canada and Canadian Forestry Service, Natural Resources Canada.

Cronan, C. S., \& Grigal, D. F. (1994). Use of Calcium/Aluminum Ratios as Indicators of Stress in Forest Ecosystems. Journal of Environmental Quality, 24, 209-226.

https://doi.org/10.2134/jeq1995.00472425002400020002x 
Crow, P. (2005). The Influence of Soils and Species on Tree Root Depth (7 p). Edinburgh: Forestry Commission.

Drever, C. R., \& Lertzman, K. P. (2001). Light-Growth Responses of Coastal Douglas-Fir and Western Red Cedar Saplings under Different Regimes of Soil Moisture and Nutrients. Canadian Journal of Forest Research, 31, 2124-2133. https://doi.org/10.1139/x01-149

Environment Canada (2017). Canadian Climate Normals 1981-2010 Station Data: Edmunston, New Brunswick. http://climate.weather.gc.ca/climate_normals/index_e.html\#1981

Fahmy, S. H., Hann, S. W. R., \& Jiao, Y. (2010). Soils of New Brunswick: The Second Approximation. Technical Publication Number: NBSWCC-PRC 2010-01, Fredericton: Agriculture and Agri-Food Canada.

Gale, M. R., \& Grigal, D. F. (1987). Vertical Root Distributions of Northern Trees in Relation to Successional Status. Canadian Journal of Forest Research, 17, 829-834. https://doi.org/10.1139/x87-131

Homagain, K., Shahi, C. K., Carmean, W. H., Mathew Leitch, M., \& Bowling, C. (2011). Growth and Yield Comparisons for Red Pine, White Spruce and Black Spruce Plantations in Northwestern Ontario. The Forestry Chronicle, 87, 494-503.

https://doi.org/10.5558/tfc2011-048

Keys, K., Noseworthy, J. D., Ogilvie, J., Burton, D. L., \& Arp, P. A. (2016). A Simple Geospatial Nutrient Budget Model for Assessing Forest Harvest Sustainability across Nova Scotia. Open Journal of Forestry, 6, 420-444. https://doi.org/10.4236/ojf.2016.65033

Kozlowski, T. T. (1985). Soil Aeration, Flooding, and Tree Growth. Journal of Arboriculture, 11, 85-96.

Langmaid, K. K, MacMillan, J. K., \& Losier, J. G. (1976). Soils of Northern Victoria County New Brunswick (152 p.). Seventh Report of the New Brunswick Soil Survey, Canada Department of Agriculture.

Lanner, R. M. (1985). On the Insensitivity of Height Growth to Spacing. Forest Ecology and Management, 13, 143-148.

Latifi, H., Fassnacht, F. E., Müller, J., Tharani, A., Dech, S., \& Heurich, M. (2015). Forest Inventories by LiDAR Data: A Comparison of Single Tree Segmentation and Metric-Based Methods for Inventories of a Heterogeneous Temperate Forest. International Journal of Applied Earth Observation and Geoinformation, 42, 162-174.

Mallik, A. U., Kamal Hossain, M. K., \& Lamb, E. G. (2008). Species and Spacing Effects of Northern Conifers on Forest Productivity and Soil Chemistry in a 50-Year-Old Common Garden Experiment. Journal of Forestry, 106, 83-90.

Masaka, K., Sato, H., Torita, H., Kon, H., \& Fukuchi, M. (2013). Thinning Effect on Height and Radial Growth of Pinus thunbergii Parlat. Trees with Special Reference to Trunk Slenderness in a Matured Coastal Forest in Hokkaido, Japan. Journal of Forest Research, 18, 475-481. https://doi.org/10.1007/s10310-012-0373-y

McKinnon, L. M., Kayahara, G. J., \& White, R. G. (2006). Biological Framework for Commercial Thinning Even-Aged Single-Species Stands of Jack Pine, White Spruce, and Black Spruce in Ontario (Report TR-046). Northeast Science and Information Section: Ontario Ministry of Natural Resources.

Murphy, P. N. C., Ogilvie, J., Meng, F.-R., White, B., Bhatti, J. S., \& Arp, P. A. (2011). Modelling and Mapping Topographic Variations in Forest Soils at High Resolution: A Case Study. Ecological Modelling, 222, 2314-2332.

New Brunswick Department of Natural Resources (2008). Bedrock Geology of New 
Brunswick. Minerals Policy and Planning Division. Map NR-1. Scale 1: 500,000 (2008 ed.).

Pinjuv, G., Mason, E. G., \& Watt, M. (2007). Incorporating an Index of Root Zone Water Balance into and Existing Growth and Yield Model Can SPBL (1.2). In D. D. Dykstra (Ed.), Forest Growth and Timber Quality: Crown Models and Simulation Methods for Sustainable Forest Management (pp. 81-97). Collingdale, PA: DIANE Publishing.

Pitt, D., \& Lateigne, L. (2008). Long-Term Outcome of Pre-Commercial Thinning in Northwestern New Brunswick: Growth and Yield of Balsam for and Red Spruce. Canadian Journal of Forest Research, 38, 592-610. https://doi.org/10.1139/X07-132

Power, H., LeMay V., Berninger, F., Sattler, D., \& Kneeshaw, D. (2012). Differences in Crown Characteristics between Black (Picea mariana) and White Spruce (Picea glauca). Canadian Journal of Forest Research, 42, 1733-1743.

https://doi.org/10.1139/x2012-106

Smith, J., Harvey B. D., Koubaa, A., Brais, S., \& Mazerolle, M. K. (2016). Sprucing up the Mixed Woods: Growth Response of White Spruce (Picea glauca) to Partial Cutting in the Eastern Canadian Boreal Forest. Canadian Journal of Forest Research, 46, 1205 1215. https://doi.org/10.1139/cjfr-2015-0489

Strunk, J. L., Reutebuch, S. E., \& Foster, J. R. (2008). LiDAR Inventory and Monitoring of a Complex Forest. In ASPRS 2008 Annual Conference Portland(8 p.).

Thorpe, H. C., Thomas S. C., \& Caspersen, J. P. (2008). Tree Mortality Following Partial Harvests Is Determined by Skidding Proximity. Ecological Applications, 18, 1652-1663. https://doi.org/10.1890/07-1697.1

Tompalski, P., Coops, N. C., White, J. C., \& Wulder, M. A. (2016). Enhancing Forest Growth and Yield Predictions with Airborne Laser Scanning Data: Increasing Spatial Detail and Optimizing Yield Curve Selection through Template Matching. Forests, 7, 255. https://doi.org/10.3390/f7110255

Treitz, P., Lim, K., Woods, M., Pitt, D., Nesbitt, D., \& Etheridge, D. (2012). LiDAR Sampling Density for Forest Resource Inventories in Ontario, Canada. Remote Sensing, 4, 830-848. https://doi.org/10.3390/rs4040830

Wang, G. G., \& Klinka, K. (1996). Use of Synoptic Variables in Predicting White Spruce Site Index. Forest Ecology and Management, 80, 95-105.

Woods, M., Pitt, D., Penner, M., Lim, K., Nesbitt, D., \& Treitz, P. (2011). Operational Implementation of a LiDAR Inventory in Boreal Ontario. The Forestry Chronicle, 87, 512-528. https://doi.org/10.5558/tfc2011-050

Wulder, M. A., White, J. C., Nelson, R. F., Næsset, E., Ørka, H. O., Coops, N. C., Hilke, T., Bater, C. W., \& Gobakken, T. (2012). Lidar Sampling for Large-Area Forest Characterization: A Review. Remote Sensing of Environment, 121, 196-209. 
Submit or recommend next manuscript to SCIRP and we will provide best service for you:

Accepting pre-submission inquiries through Email, Facebook, LinkedIn, Twitter, etc. A wide selection of journals (inclusive of 9 subjects, more than 200 journals)

Providing 24-hour high-quality service

User-friendly online submission system

Fair and swift peer-review system

Efficient typesetting and proofreading procedure

Display of the result of downloads and visits, as well as the number of cited articles Maximum dissemination of your research work

Submit your manuscript at: http://papersubmission.scirp.org/

Or contact ojf@scirp.org 